\title{
A path analysis of customer loyalty of homegrown coffee shops in Davao region
}

\author{
Hinlayagan Kymwell Recamadas* \\ University of Mindanao, Davao, Philippines
}

\section{Keywords \\ Path analysis \\ Customer loyalty \\ Homegrown coffee shops}

Received: 8 June 2018

Accepted: 11 July 2018

Published: 2 August 2018

\begin{abstract}
The study's main purpose is to determine the factors that lead to customer loyalty to homegrown coffee shops. This study was also conducted to investigate the relationship of the marketing mix, customer expectation, customer experience, customer satisfaction, and customer loyalty among homegrown coffee shops. The quantitative study utilized a descriptive correlational and causal-comparative approach as the research design was utilized in this study. The study employed path analysis to allow the testing of a hypothesis based on a proposed causal model. The data were obtained from the 580 homegrown coffee shop customers in Davao Region, Philippines. Sets of questionnaires were used as instruments. Pearson product-moment correlation was used to determine the interrelationships between the marketing mix, customer expectation, customer experience, and customer satisfaction to customer loyalty. Multiple linear regression was performed to determine the significant predictor of customer loyalty. Path analysis was utilized to analyze the path relationships among the variables. The study's findings revealed that the level of the marketing mix, the level of customer expectation, the level of customer experience, the level of customer satisfaction, and customer loyalty as perceived by the customers of homegrown coffee shops were all rated highly. This means high customer satisfaction and customer loyalty in homegrown coffee shops in Davao Region. Moreover, marketing mix, customer expectation, customer experience, and customer satisfaction were highly correlated to customer loyalty. This indicates that marketing mix, customer expectation, customer experience, and customer satisfaction would directly affect customer loyalty. Meanwhile, all exogenous variables have a significant direct influence on customer loyalty. Furthermore, the final model passed all the goodness of fit indices criteria CMIN/DF, $p$-value, TLI, CFI, GFI, RMSEA, PCLOSE.
\end{abstract}

(C) 2018 The Author(s). Published by TAF Publishing.

\section{INTRODUCTION}

The importance of customers has been highlighted by lots of researchers and entrepreneurs around the world. That is the main reason why businesses today are focusing much attention on customer satisfaction and customer loyalty. On the other hand, coffee shop is a promising business in today's generation, and many entrepreneurs are investing in this industry. With this, increasing number of businesses offering the same kind of products became a problem of every company. That is why customer satisfaction is considered very important because it leads to higher customer loyalty.

In a business world where competitors are only a click away, customer loyalty really is the new marketing strat- egy (Ciotti, 2017; Davey, 2014; Saputra \& Dewi, 2016). Today's customers are willing to stick with companies who meet customer expectation and create a fantastic customer experience (Kim \& Mauborgne, 2014; Kuo \& Chen, 2015). Coffee is second most consumed beverage in the world after water (Gma News Online, 2014; Pablo, 2016). Consequently, with the high demand for coffee and the existence of many coffee shops in the market, businesses are becoming similar. If a company wants to survive, the concept of customer loyalty needs to be emphasized (Peck, Christopher, Clark, \& Payne, 2013; Tsai \& Tsai, 2017). Therefore, companies focus on brand building in the endeavor of attaining customer loyalty by developing marketing mix, knowing customer expectation, giving best customer expe-

\footnotetext{
*corresponding author: Hinlayagan Kymwell Recamadas

†email: hinlayagan_kymwell@yahoo.com
} 
rience, and meeting customer satisfaction (Ene \& Ozkaya, 2014; Intan, 2016).

As mentioned by Ingram (2017) coffee shop is one of the promising businesses in today's generation, with the high market demand and showing unique experience to the customers so, different local entrepreneurs are applying different strategies in attaining customer loyalty (Chiang, 2013; Kumar, 2015; Zhang \& Chung, 2016). To compete with international brand, a company which started in its origin may have a deep understanding on different aspects of attracting customer loyalty. This can be achieved by knowing the customer expectation and meeting customer satisfaction (Clarke, Ta maschke, \& Liesch, 2013; Ramly \& Omar, 2016).

Consequently, Kumar (2015) stated that homegrown coffee shop refers to the businesses originated in the place where it is located. Local coffee shops can establish a solid reputation in the communities, attracting large volume of loyal customer (Chiang, 2013; Nugraha \& Indrawati, 2017; Pablo, 2016). Marketing a homegrown coffee shop requires more subtlety than other international businesses. One of the most important challenges that leaders face is to devise and execute strategies that speed up revenue growth (Strydom, 2005).

Large parts of the United States and Canada are being afflicted by a small coffee shop business problem due to lack of knowledge in applying different marketing strategy and not meeting customer's expectation that leads to customer dissatisfaction (Krisnawati, Perangin Angin, Zainal, \& Suardi, 2016; Liang \& Wu, 2012). Different coffee company has acknowledged the problem, saying it is the result of troubles with a lack of marketing plan and strategies on how to build customer loyalty (Roberts, 2017). In Israel, Starbucks failed after 2 years of operation, the company stated that it closed the stores due to ongoing operational challenges which refer to failure in marketing forecast and different type of market as compared to other country where the company lead the coffee industry (Steinberg, 2014).

In recent years, there has been an accelerated growth in the ASEAN café market showing its potentials for homegrown café brands, five highlighted markets are Vietnam, Malaysia, Thailand, Indonesia and the Philippines. Common issue in the coffee shop business in these countries is the lack of marketing strategy that resulted to the decrease of industry market share to the country (Nguyen, 2016). Philippines is one of the top producer of coffee in the world and a country with high coffee consumption.

This means that coffee shop would become the main force in the market (Crane \& Matten, 2016). But the status of cof- fee shops in the Philippines specifically in Batangas City is becoming low in terms of its customers' satisfaction, due to the escalating number of coffee shops around having similar business marketing strategies that resulted to poor customer experience (Barlan \& Leoncio, 2013).

Davao Region is the second top coffee producer in the Philippines (Pablo, 2016). Many coffee shops are opening in the city due to increase of business opportunity in the area (Cranston, 2014; Villarreiz, 2012) the challenge is becoming unique as compared to the other business offering the same kind of product became a problem. Moreover, Smith and $\mathrm{Hu}$ (2013), consider areas like bad marketing strategy, not meeting customer expectation, poor customer experience and lack of customer satisfaction, as part of the problem that every coffee shop business is experiencing.

Although, there have been studies on coffee shop business such as the analysis of coffee shop market in the United States (Liang \& Wu, 2012) and the impact of branded environments on customer preferences in coffee shops in Florida (Kibler, 2015), these studies focus more on various effects and role in the different industries. Few studies have really focused on the role and effects of the 1.7 billion customers in the coffee industry (Aljunied, 2013; Friend, 2016). Knowing that, Philippines is a country with high coffee consumption and is going to become the main force in the market (Crane \& Matten, 2016).

Every homegrown coffee shop has its own strategies and programs to attract new customers and retain the current ones (Peck et al., 2013). However, the impacts of these strategies and others on the customer's loyalty to homegrown coffee shops have not been investigated widely (Hussain, Al Nasser, \& Hussain, 2015; Mitra, 2016; Oliver, 2014). Therefore, it needs to be considered if there is such a thing as customer satisfaction that leads to customer's loyalty when people purchase coffee, and where does the customer satisfaction and loyalty come from.

In addition, Mohsan, Nawaz, Khan, Shaukat, and Aslam (2011) stated that previous researches have attempted to examine the link between customer satisfaction and customer loyalty. However, the researcher had not come across readings linking homegrown coffee shops with marketing mix, customer expectation, customer experience, customer satisfaction, and customer loyalty. Therefore, there still lack of researches in customer loyalty of homegrown coffee shops to investigate.

This study was anchored on the Social Exchange Theory (Homans, 1958). This theory explains the relationships between customer satisfaction and customer loyalty, which posits that all human relationships are formed by the use of 
cost and benefit analysis and comparisons of alternatives. The author suggested that when an individual perceives that the cost of a relationship outweighs the perceived benefits, then the person will choose to leave the relationship.

\section{Objective of the Study}

The current study aimed at investigating the relationship, influence and best fit model between marketing mix, customer expectation, customer experience, and customer satisfaction to customer loyalty in homegrown coffee shops in Davao Region.

\section{LITERATURE REVIEW Marketing Mix}

As mentioned by Strydom (2005) every business organization faces a different marketing challenge that is why different entrepreneurs are applying different strategies in order to establish customer loyalty. In addition, Chiang (2013) and Kumar (2015) stated that marketing strategies of different companies are evolving and changing depending on the expectation set by market. To introduce the business in international market companies have a deep understanding on different aspect of marketing to attain customer loyalty (Clarke et al., 2013; Wichailert \& Yousapornpaiboon, 2017). In addition, Ingram (2017) sited that marketing a coffee shop needs different strategies in attaining success in the business. Al-Debi and Mustafa (2014) and Umeze, Ohen, et al. (2015) stated that business greatly relies on the product, price, place, promotion, people, process, and physical evidence known as marketing mix which is a factor in attaining customer satisfaction and customer loyalty.

\section{Customer Expectation}

As pointed out by Nabi (2012), customer expectation refers to the different beliefs of the customers to the company that serves as customer standard. Oliver (2014) said that customer expectation is formed by different uncontrollable factors. In addition, Bowie, Buttle, Brookes, and Mariussen (2016) stated that customer expectation is made of complex considerations, including own pre-purchase beliefs and other customers opinions (Rafiah \& Ariyanti, 2017; Umbach, Schwager, Frensch, \& Gaschler, 2012).

Furthermore, the influences of customer expectation are pre-purchased; the word of mouth from the other customer can be a great factor (O'Connor, 2008). In addition, Esangbedo (2014) and Toporek (2013) stated that customers expect certain things when experiencing new things, and when companies able to meet customer expectation it will surely attain customer loyalty. If customer expectations meet by the company it will attain customer satis- faction. Loizos and Lycourgos (2005) enumerated the different types of expectations of customer which refers to explicit expectations, implicit expectations, static performance expectations, situational expectations, interpersonal expectations, dynamic performance expectations, and technological expectations.

\section{Customer Experience}

Enhancing customer experience is an absolute priority of every business organization today. The following are the top seven indicators that every company may consider in measuring customer experience this refers to the ease, novelty, learning, comfort, personal, relax, and involvement (Deshwal \& Khanna, 2013).

Based on the profiling made by Vanharanta, Kantola, and Seikola (2015) the new trend in the leading international companies is to have a strong customer experience (Rocco, 2016). In addition De Luca and Pegan (2014) added that the company knows its customers to give the suited customer experience based on the personality of the customer; a more personalized service and customized experience can be developed by a company to develop great company to customer relationship.

\section{Customer Satisfaction}

Emphasized, by Oliver (2014) customer satisfaction comes from great customers experience. Marketing mix and customer experience are all important factors contributing to high levels of customer satisfaction and they are qualities that are basic elements that a company may focus on to gain customer loyalty. Moreover, Zikmund, Babin, Carr, and Griffin (2010) as well as Daniel and Berinyuy (2010) states that customer satisfaction is an overall attitude formed based on the experience after customers purchase a product or experience the service. Satisfaction is the assessment of the experience of interacting with a service provider up to the present time, and is used by customers to predict future experience (Rahmani, Firoozbakht, \& Taghipoor, 2014). In addition, Amissah (2013), and Yulisetiarini and Si (2016) and Amissah (2013) enumerated the indicators that identifies customer satisfaction which refers to reliability, responsiveness, assurance, empathy, and tangibles.

\section{Customer Loyalty}

Emphasized by Dogdubay and Avcikurt (2013) that customer loyalty depends on how customer compares a perceived performance of a product and expectations; wherein customer feel satisfied if the perceived performance is better than the expectation. Loyal customers tend to market the business through the word of mouth. According 
to Rahmani et al. (2014) customer loyalty is an important objective for strategic marketing planning and represents an important basis for developing a sustainable competitive advantage. Customer loyalty leads to increase business value and lower the cost of the business (Kolowich, 2017). Today companies are more focused on customer loyalty; it takes five times as much effort, time and money to attract a new customer than it does keeping an existing customer (Peppers \& Rogers, 2016). Additionally, customer satisfaction will contribute profit to the company and eventually this also positively results to customer loyalty. Lastly, cus- tomer loyalty is categorized into behavioural loyalty, attitudinal loyalty, and composite loyalty (Bowen \& Chen, 2001). In general, customer loyalty has been defined as the highest form of customer service (Griffin \& Herres, 2002). Through the different factors that contribute to the attainment of every business goals and objectives.

\section{RESEARCH MODEL}

Below is the research model of the study. Marketing mix, customer expectation, customer experience, and customer satisfaction are positively related to customer loyalty.

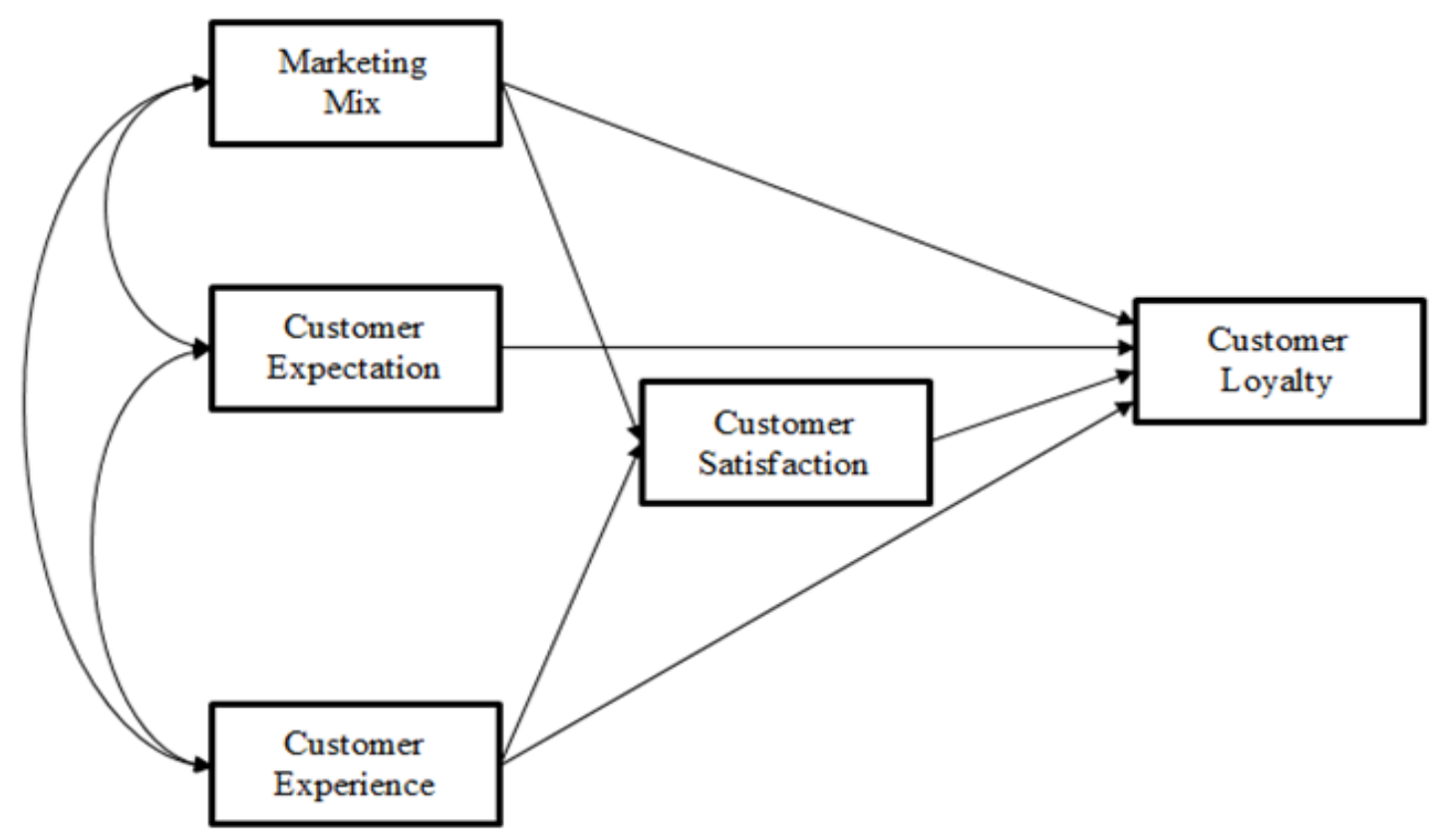

FIGURE 1. Research model

\section{METHODOLOGY}

This quantitative study utilized descriptive correlational and causal comparative approach as the research design. Quantitative research is the systematic empirical investigation of observable phenomena via statistical, mathematical or computational techniques. According to Helson (1948) the objective of quantitative research is to develop and employ mathematical models, theories and hypotheses pertaining to phenomena. The process of measurement is central to quantitative research because it provides the fundamental connection between empirical observation and mathematical expression of quantitative relationships (Phan \& Nguyen, 2016). This study employed path analysis. Path analysis allows testing of hypothesis based on a proposed causal model. Path analysis enables simultaneous analysis of multiple independent variables on a criterion variable these are the exogenous and endogenous vari- ables (Shipley, 2016; Wuensch, 2016). Exogenous variables are those variables whose causes are not explicitly represented in the model.

This study utilized descriptive correlation method to test the relationship and influence of marketing mix, customer expectation, customer experience, customer satisfaction to customer loyalty towards homegrown coffee shop customers in Davao Region. There were 580 respondents in the study. The statistical tools used were path analysis, stepwise regression, mean and standard deviation.

An adapted survey instrument patterned after the original work of Al-Debi and Mustafa (2014), Umeze et al. (2015) for marketing mix indicators, Loizos and Lycourgos (2005) for customer expectations, Deshwal and Khanna (2013) for customer experience indicators; the questions under satisfactions are from the study of Amissah (2013), Yulisetiarini and $\mathrm{Si}$ (2016), the instrument for customer loyalty are from 
the study of Huang and Wonglorsaichon (2013). Hypothesis of the study states that there is a significant relationship and influence between marketing mix, customer expectation, customer experience and customer satisfaction to customer loyalty.

\section{RESULTS AND DISCUSSION}

Mean of marketing mix was found to be $5.98(S D=0.69)$, customer expectation mean is $6.16(S D=0.70)$, customer experience mean is $6.16(S D=0.70)$, while customer satisfaction mean is $6.20(S D=0.69)$, and customer loyalty mean is $6.12(S D=0.84)$. Descriptive Statistics can be seen in the Table 1 below.

It means that the customers of homegrown coffee shops strongly agree with the marketing mix, customer expectation, customer experience, customer satisfaction and customer loyalty statement.

TABLE 1. Level of marketing mix, customer expectation, customer experience, customer satisfaction and customer loyalty

\begin{tabular}{llcc}
\hline \hline Item & Mean & Standard Deviation & Description Level \\
\hline Marketing mix & 5.98 & 0.69 & High \\
Customer expectation & 6.16 & 0.70 & High \\
Customer experience & 6.16 & 0.70 & High \\
Customer satisfaction & 6.20 & 0.69 & High \\
Customer loyalty & 6.12 & 0.84 & High \\
\hline \hline
\end{tabular}

Marketing mix is a business tool that is used by the management of organizations which enable them to remain in global competitive environment. It is the set of controllable, tactical marketing tools of product, price, place, promotion, people, process, and physical evidence which are the variables that marketing managers can control in order to best satisfy customer needs and wants (Owomoyela, Oyeniyi, \& Ola, 2013; Yasanallah \& Bidram, 2012).

The result of the study emphasized the statement of Hussain et al. (2015) and Oliver (2014) that customer satisfaction comes from customers that meet or exceed customer expectation and customer experience a good quality service. Customers become satisfied when the expectations meet from the quality of the service provided by the companies (Rahmani et al., 2014). In addition the study conducted by Worley, Williams, Williams, and Lawler (2014) added that customer satisfaction reflects the expectations that the customer has experienced with a product or service (Agnihotri, Dingus, Hu, \& Krush, 2016).

The overall result in the level of customer loyalty supports the study of Hand Ground (2013) that customer loyalty depends on how customer compares a performance of a product and the attachment to the company (Carter, 2014). This means that, customer loyalty is an important objective for strategic marketing planning and represents an important basis for developing a sustainable competitive advantage (Wu \& Tseng, 2014). Moreover, Musikapart (2013) considered customer loyalty as the highest form of business success in terms of retaining and keeping long term customer and attracting new one.
Relationship of Marketing Mix, Customer Expectation, Customer Experience, and Customer Satisfaction to Customer Loyalty

Table 2 shows that all exogenous variables are significantly correlated to customer loyalty. This means that marketing mix, customer expectation, customer experience, and customer satisfaction has a significant relationship with customer loyalty. In addition knowing marketing mix, identifying customer expectation, giving best customer experience and meeting customer satisfaction develops customer loyalty. Customer loyalty can be achieved through attaining customer satisfaction (Wu \& Tseng, 2014). That's why different organizations create a unique ways that can adopt the ever changing nature of the service industry (Daikh, 2015). In the contrary, time constraints are most often a barrier to customer satisfaction (Phan \& Nguyen, 2016). That is why every business organization in the market competes to develop advanced methods to keep on track (Shaikh, Amjad, Khan, \& Ur, 2011). Technology, for example affects the customer satisfaction, since constantly meeting customer satisfaction over a period of time is the only way to achieve customer loyalty (Nam \& Carnie, 2014). It is a basic logic that satisfied customers will probably and eventually return to the company for future purchases and eventually become loyal customer (Hussain et al., 2015). 
TABLE 2. Relationship of marketing mix, customer expectation, customer experience, and customer satisfaction to customer loyalty

\begin{tabular}{llll}
\hline \hline Exogenous Variables & Customer Loyalty & & \\
\cline { 2 - 4 } & $\boldsymbol{R}$ & $\boldsymbol{p}$-Value & Remarks \\
\hline Marketing mix & $.590^{* *}$ & .000 & Significant \\
Customer expectation & $.354^{* *}$ & .000 & Significant \\
Customer experience & $.680^{* *}$ & .000 & Significant \\
Customer satisfaction & $.693^{* *}$ & .000 & Significant \\
\hline \hline
\end{tabular}

Legend: ${ }^{* *}$ Correlation is significant at the 0.05 level ( 2 tailed)

$R$-Pearson Correlation $(r)$

Influence of Marketing Mix, Customer Expectation, Customer Experience, and Customer Satisfaction to the Customer Loyalty

Table 3 shows that marketing mix, customer expectation, customer experience and customer satisfaction influence customer loyalty. The stepwise regression analysis shows that, an increase in marketing mix, customer experience and customer satisfaction also increase customer loyalty. On the other hand, the increase in customer expectation means a decrease in customer loyalty.

The result of the study of $(\mathrm{Li}, 2015)$ about the relationship of customer expectation to customer loyalty states that there is a strong correlation between exceeding customer expectation and growing customer loyalty, but in reality when the company meets customer expectation the loyalty growth slows and customers are not more loyal even if the business management put and extra effort. Since customer loyalty is often linked to business success, it's the perfect medium for addressing each of customer expectations simultaneously which means that each and every company know how to identify customer expectation to attain customer loyalty (Bowie et al., 2016).

The study conducted by Mohsan et al. (2011) on the impact of customer satisfaction on customer loyalty has a higher regression result as compared with study with 80 percent, the variance of customer loyalty in the study was explained by customer satisfaction.

TABLE 3. Influence of marketing mix, customer expectation, customer experience, and customer satisfaction to the customer loyalty

\begin{tabular}{llllllll}
\hline \hline \multirow{2}{*}{ Exogenous Variables } & \multicolumn{2}{l}{ Unstandardized Coefficients } & \multicolumn{2}{l}{ Standardized Coefficients } & & & \\
\cline { 2 - 5 } & $\beta$ & Std. Error & $\beta$ & & & $\boldsymbol{p}$-Value & Remarks \\
\hline Constant & .802 & .243 & & 3.298 & .001 & \\
Marketing mix & .228 & .057 & .188 & 3.988 & .000 & Significant \\
Customer expectation & -.209 & .046 & -.175 & -4.584 & .000 & Significant \\
Customer experience & .392 & .067 & .326 & 5.869 & .000 & Significant \\
Customer satisfaction & .458 & .069 & .380 & 6.683 & .000 & Significant \\
\hline \hline
\end{tabular}

Note: $R=.731, R$-square $=.534, F=164.650, p<.05$

\section{BEST FIT MODEL OF CUSTOMER LOYALTY}

Results of the path analysis of the hypothesized model are shown in Figure 2. The analysis reveals a strong and positive correlation between marketing mix, customer expectation and customer experience. It can also be seen that marketing mix and customer experience significantly predicts customer satisfaction. This further suggests that marketing mix and customer experience exerts a significant factor to the customer satisfaction of homegrown coffee shops.

On the other hand, marketing mix, customer experience, and customer satisfaction appears to have a positive direct influence to customer loyalty in the homegrown coffee shops. This means that for every unit increase in the marketing mix, customer experience, and customer satisfaction, there is a corresponding increase in the customer loyalty by .19 for marketing mix, .33 for customer expectation, and .38 for customer satisfaction. This implies that marketing mix, customer experience, and customer satisfaction contributes to the customer loyalty of homegrown coffee shops in Davao Region. Meanwhile customer expectation has a negative influence to customer loyalty in homegrown coffee shops. It means that for every unit increase in customer expectation there is a corresponding decrease in the customer loyalty by -.18

Moreover, marketing mix and customer experience explained 75 percent of the variance of the customer satisfaction to customer loyalty. The results of the path analysis also show that the squared multiple correlations equal to 0.54 . This indicates that $54 \%$ of the variation in the customer loyalty can be explained by the study. 


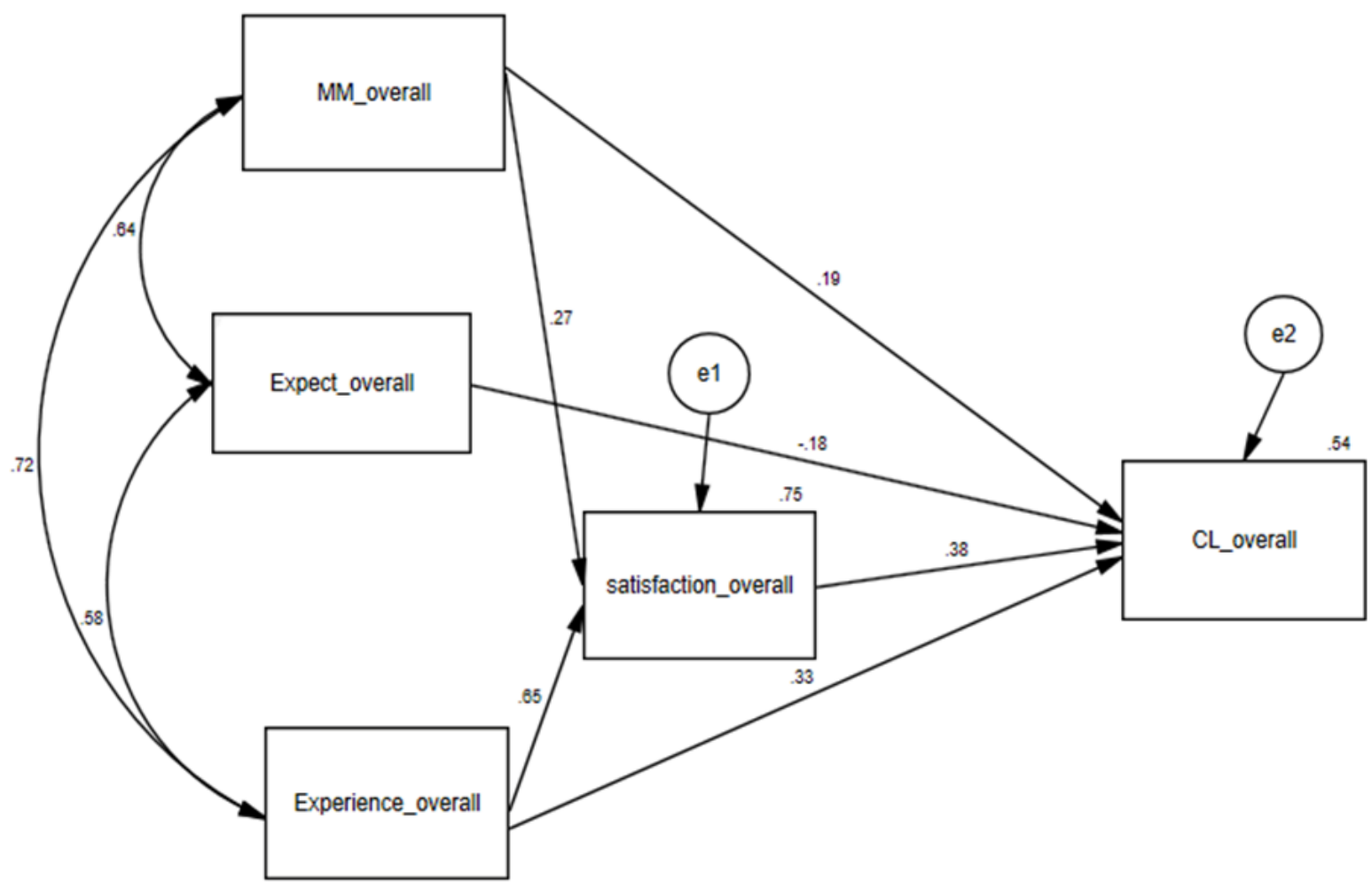

FIGURE 2. Best fit model of customer loyalty

The results for best fit model goodness of fit measure. As can be seen in the results, model fit values have successfully meet the criteria set by each index, the fit indicates are 2.548 for CMIN/DF, .110 for $p$-value, .992 for Tucker-Lewis Index (TLI), . 999 for Comparative Fit Index (CFI), .998 for Goodness of Fit Index (GFI), and .052 for Root Mean Square Error of Approximation (RMSEA). These show that all the fit indices have been met and that the model fits the data.

\section{CONCLUSION}

The marketing mix, customer expectation, customer experience, customer satisfaction and customer loyalty is highly evident in homegrown coffee shop industry. Homegrown coffee shop can have a possibility in attaining the highest level of customer loyalty by maintaining a high level of marketing mix, customer expectation, customer experience and customer satisfaction. this can be said that market- ing mix, customer expectation, customer experience, and customer satisfaction is highly correlated with customer loyalty. Hence, marketing mix, customer expectation, customer experience, and customer satisfaction influence customer loyalty.

The best fit model shows a relationship between marketing mix, customer expectation, customer experience, and customer satisfaction to customer loyalty. The marketing mix and customer experience have a direct effect on satisfaction. For every increase in the marketing mix, customer experience and satisfaction, there is a corresponding increase in customer loyalty. On the other hand, in every increase in customer expectation means a decrease in customer loyalty. Future researches may be undertaken to introduce other variables which explore the other field aside from marketing mix, customer expectation, customer experience, and customer satisfaction on attaining customer loyalty.

\section{REFERENCES}

Agnihotri, R., Dingus, R., Hu, M. Y., \& Krush, M. T. (2016). Social media: Influencing customer satisfaction in B2B sales. Industrial Marketing Management, 53, 172-180. doi:https://doi.org/10.1016/j.indmarman.2015.09.003

Al-Debi, H. A., \& Mustafa, A. (2014). The impact of services marketing mix 7p's in competitive advantage to five stars hotel-case study Amman, Jordan. In Academic Conference on the Clute Institute International, Jordan, Amman.

Aljunied, K. (2013). Coffee shops in colonial Singapore: Domains of contentious publics. History Workshop Journal, 77(1), 65-85. doi:https://doi.org/10.1093/hwj/dbt011 
Amissah, E. F. (2013). Tourist satisfaction with hotel services in Cape Coast and Elmina, Ghana. American Journal of Tourism Management, 2(3), 26-33.

Barlan, J. R., \& Leoncio, F. (2013). Status of coffee shop business in Batangas city: Basis for business operation initiatives. International Journal of Academic Research in Business and Social Sciences, 3(8), 351-370. doi:https://doi.org/10 $.6007 /$ ijarbss/v3-i8/156

Bowen, J. T., \& Chen, S.-L. (2001). The relationship between customer loyalty and customer satisfaction. International Journal of Contemporary Hospitality Management, 13(5), 213-217. Retrieved from https://doi.org/10.1108/ 09596110110395893

Bowie, D., Buttle, F., Brookes, M., \& Mariussen, A. (2016). Hospitality marketing. London, UK: Routledge.

Carter, B. (2014). The two types of loyalty and how to earn them. Retrieved from https://goo.gl/nGcs19 (accessed on 23 July 2017)

Chiang, W. Y. (2013). Applying data mining on customer relationship management system for leisure coffee shop industry: A case study in Taiwan. Wiley Interdisciplinary Reviews: Data Mining and Knowledge Discovery, 3(2), 129-139. doi: https://doi.org/10.1002/widm.1084

Ciotti, G. (2017). The art of customer loyalty. Retrieved from https://goo.gl/YGS8Jf (accessed on 24 July 2018)

Clarke, J. E., Tamaschke, R., \& Liesch, P. W. (2013). International experience in international business research: A conceptualization and exploration of key themes. International Journal of Management Reviews, 15(3), 265-279.

Crane, A., \& Matten, D. (2016). Business ethics: Managing corporate citizenship and sustainability in the age of globalization. Oxford, UK: Oxford University Press.

Cranston, J. (2014). Our hopes for philippine farmers and our prayers for coffee for peace. Retrieved from https://goo.gl/ MK6J9B (accessed on 15 June 2016)

Daikh, J. (2015). A research proposal: The relationship between customer satisfaction and consumer loyalty. Retrieved from https://goo.gl/xXfzpb (accessed on 1 July 2016)

Daniel, C. N., \& Berinyuy, L. (2010). Using the servqual model to assess service quality and customer satisfaction. Retrieved from https://goo.gl/yGqRHb (accessed on 14 August, 2012)

Davey, N. (2014). Emotional vs transactional loyalty: Is it more important to win hearts or minds? Retrieved from https: // goo.gl/SPvSTJ (accessed on 15 September 2015)

De Luca, P., \& Pegan, G. (2014). The coffee shop and customer experience: A study of the US market. In Musso, F., \& Druica, E. (Eds.), Handbook of research on retailer-consumer relationship development. New York, NY: IGI Global.

Deshwal, P., \& Khanna, S. (2013). Service experience and consumer satisfaction in restaurants. International Journal of Business and Management Invention, 2(1), 89-95.

Dogdubay, M., \& Avcikurt, C. (2013). Customer loyalty in the specialty restaurants: An example from Istanbul. Retrieved from https://goo.gl/9ctZxM (accessed on 23 January 2015)

Ene, S., \& Ozkaya, B. (2014). A study on corporate image, customer satisfaction and brand loyalty in the context of retail stores. Asian Social Science, 10(14), 52-60. doi:https://doi.org/10.5539/ass.v10n14p52

Esangbedo, L. (2014). The importance of meeting customer expectation (serving the coffee: Hospitality and conferencing). Retrieved from https://goo.gl/pyQaPn (accessed on 23 June 2016)

Friend, E. (2016). Coffee shops around the world: Three key insights for 2016. Retrieved from https://goo.gl/BCirNA (accessed on 2 July 2017)

Gma News Online. (2014). Produce more coffee, DTI tells SMEs. Retrieved from https://goo.gl/14zGiz (accessed on 16 July 2016)

Griffin, J., \& Herres, R. T. (2002). Customer loyalty: How to earn it, how to keep it. San Francisco, CA: Jossey-Bass.

Hand Ground. (2013). How to measure customer loyalty: 3 easy steps to build a better business. Retrieved from https: / goo.gl/jk63Bz (accessed on 21 April 2018)

Helson, H. (1948). Adaptation-level as a basis for a quantitative theory of frames of reference. Psychological Review, 55(6), 297-313. doi:https://doi.org/10.1037/h0056721

Homans, G. C. (1958). Social behavior as exchange. American Journal of Sociology, 63(6), 597-606. doi:ttps://doi.org/ $10.1086 / 222355$ 
Huang, X., \& Wonglorsaichon, P. (2013). The effect of customer loyalty program and service quality on customer loyalty: Hypermarket in Bangkok (Unpublished matser's thesis). School of Business, University of the Thai Chamber of Commerce, Bangkok, Thailand.

Hussain, R., Al Nasser, A., \& Hussain, Y. K. (2015). Service quality and customer satisfaction of a UAE-based airline: An empirical investigation. Journal of Air Transport Management, 42, 167-175. doi:https://doi.org/10.1016/j.jairtraman .2014.10.001

Ingram, D. (2017). Coffee shop marketing strategies. Retrieved from https://goo.gl/ykTJ44 (accessed on 14 July 2017)

Intan, W. S. (2016). The analysis factors of experential marketing, product quality, and customer satisfaction of motor bike as a main transportation mode in Bandung-Indonesia. International Journal of Business and Administrative Studies, 2(1), 6-8. doi:https://doi.org/10.20469/ijbas.2.10002-1

Kibler, S. P. (2015). Impact of branded environments on user preferences in coffee shops and cafés. Retrieved from https:// goo.gl/QH98He (accessed on 15 Spetmebr, 2017)

Kim, W. C., \& Mauborgne, R. A. (2014). Blue ocean strategy, expanded edition: How to create uncontested market space and make the competition irrelevant. Boston, MA: Harvard Business Review Press.

Kolowich, L. (2017). 8 of the top marketing challenges marketers will face this year and 7 customer loyalty programs that actually add value. Retrieved from https://goo.gl/oS2Bhj (accessed on 1 November, 2017)

Krisnawati, N., Perangin Angin, L. K., Zainal, M., \& Suardi, I. (2016). Brand equity analysis and its impact on the loyal customer of local batik to develop its competitiveness (An empirical study of batik Banten in south Tangerang). Journal of Administrative and Business Studies, 2(4), 189-207. doi:https://doi.org/10.20474/jabs-2.4.5

Kumar, V. (2015). Evolution of marketing as a discipline: What has happened and what to look out for. Journal of Marketing, 79(1), 1-9. doi:https://doi.org/10.1509/jm.79.1.1

Kuo, M. P., \& Chen, Y. M. (2015). A study on the relationships among body sensory experience, customer satisfaction and customer loyalty-beauty SPA enter as an example. International Journal of Business and Administrative Studies, 1(2), 61-67. doi:ttps://doi.org/10.20469/ijbas.10003-2

$\mathrm{Li}$, A. (2015). The relationship between customer loyalty and expectation. Retrieved from https://goo.gl/5FH5kc (accessed on 2 July, 2016)

Liang, W. K., \& Wu, R. A. (2012). Analysis of coffee shop market in UK. Retrieved from https://goo.gl/WbAAyC (accessed on 17 December, 2016)

Loizos, C., \& Lycourgos, H. (2005). A customer's expectation and perception of hotel service quality in Cyprus. Hospitality Review, 23(2), 5-16.

Mitra, A. (2016). Fundamentals of quality control and improvement. New York, NY: John Wiley \& Sons.

Mohsan, F., Nawaz, M. M., Khan, M. S., Shaukat, Z., \& Aslam, N. (2011). Impact of customer satisfaction on customer loyalty and intentions to switch: Evidence from banking sector of Pakistan. International Journal of Business and Social Science, 2(16), 45-67.

Musikapart, N. A. (2013). The effect of brand experience and customer satisfaction on brand loyalty a case study of the true coffee in Bangkok, Thailand (Unpublished master's thesis). Prince of Songkla University, Hat Yai, Thailand.

Nabi, N. (2012). Customer expectations of service quality: A study on private banks of Bangladesh. World Review of Business Research, 2(4), 172-186. doi:https://doi.org/10.4135/9781483346366.n38

Nam, K. W., \& Carnie, B. W. (2014). Design effectiveness: Building customer satisfaction and loyalty through design. In Proceedings of Design's Big Debates, Umeå, Sweden.

Nguyen, T. P. A. (2016). The cafe market 1 among 5 ASEAN countries. Retrieved from https://goo.gl/BHfGRv (accessed on 14 July 2017)

Nugraha, P. A., \& Indrawati. (2017). The effect of social media experiential marketing towards customers' satisfaction (A study in Chingu Korean fan cafe Bandung Indonesia). International Journal of Business and Administrative Studies, 3(2), 56-63. doi:https://doi.org/10.20469/ijbas.3.10002-2

O'Connor, M. (2008). To investigate customer expectations and perceptions of service in the restaurant sector (Unpublished master's thesis). School of Hospitality Management and Tourism, Dublin Institute of Technology, Dublin, Ireland.

Oliver, R. L. (2014). Satisfaction: A behavioral perspective on the consumer: A behavioral perspective on the consumer. London, UK: Routledge. 
Owomoyela, S. K., Oyeniyi, K. O., \& Ola, O. S. (2013). Investigating the impact of marketing mix elements on consumer loyalty: An empirical study on nigerian breweries plc. Interdisciplinary Journal of Contemporary Research in Business, 4(11), 485-496.

Pablo, M. (2016). Coffee industry road map localization. Retrieved from https://goo.gl/465Z4R (accessed on 3 June, 2017)

Peck, H., Christopher, M., Clark, M., \& Payne, A. (2013). Relationship marketing. London, UK: Routledge.

Peppers, D., \& Rogers, M. (2016). Managing customer experience and relationships: A strategic framework. New York, NY: John Wiley \& Sons.

Phan, T., \& Nguyen, T. (2016). An analysis of factors impact on customer satisfaction in Vietnam restaurants: Case of fast food restaurants. International Journal of Business and Management Review, 4(6), 1-17.

Rafiah, K. K., \& Ariyanti, M. (2017). Role of transactional quality and relational quality to customer e-loyalty in marketplace C2C in Indonesia. International Journal of Business and Economic Affairs, 2(2), 116-126. doi:https://doi.org/10.24088/ ijbea-2017-22005

Rahmani, N. L., Firoozbakht, Z., \& Taghipoor, A. (2014). Service quality, relationship quality and customer loyalty (Case study: Banking industry in Iran). Open Journal of Social Sciences, 2(04), 262. doi:https://doi.org/10.4236/jss.2014.24028

Ramly, S. M., \& Omar, N. A. (2016). The relative contribution of loyalty programs and store attributes to store engagement and equity. Journal of Administrative and Business Studies, 1(1), 42-52. doi:https://doi.org/10.20474/jabs-1.1.7

Roberts, J. J. (2017). Starbucks registers down in widespread outage. Retrieved from https://goo.gl/3GxrZj (accessed on 2 June, 208)

Rocco, M. (2016). Top 7 KPI's to measure your customer experience levels. Retrieved from https://goo.gl/kyZzR4

Saputra, R., \& Dewi, C. K. (2016). The impact of brand trust on brand loyalty mediated by customer satisfaction: Case of Tokobagus.com (now OLX.co.id). Journal of Administrative and Business Studies, 1(1), 8-13. doi:https://doi.org/ 10.20474/jabs-1.1.2

Shaikh, A., Amjad, U., Khan, R., \& Ur, N. (2011). Impact of service quality on customer satisfaction: Evidences from the restaurant industry in Pakistan. Management \& Marketing Journal, 9(2), 45-60.

Shipley, B. (2016). Cause and correlation in biology: A user's guide to path analysis, structural equations and causal inference. Boston, MA: Cambridge University Press.

Smith, M. J., \& Hu, D. (2013). Not a simple coffee shop: Local, global and glocal dimensions of the consumption of starbucks in China. Social Identities, 19(5), 670-684. doi:https://doi.org/10.1080/13504630.2013.835509

Steinberg, J. (2014). The grande coffee plan that failed. Retrieved from https://goo.gl/5PZS1P (accessed on 3 October, 2016)

Strydom, J. (2005). Introduction to marketing. Claremont, CA: Juta and Company Ltd.

Toporek, A. (2013). 9 keys to managing customer expectations. Retrieved from https://goo.gl/ia7tvJ (accessed on 4 July, 2016)

Tsai, M. S., \& Tsai, M. C. (2017). The influence of loyalty, participation and obedience on organizational citizenship behavior. International Journal of Business and Economic Affairs, 2(1), 67-76. doi:https://doi.org/10.24088/ijbea-2017-21009

Umbach, V. J., Schwager, S., Frensch, P. A., \& Gaschler, R. (2012). Does explicit expectation really affect preparation? Frontiers in Psychology, 3, 378-390. doi:https://doi.org/10.3389/fpsyg.2012.00378

Umeze, G. E., Ohen, S. B., et al. (2015). Marketing mix strategies and entrepreneurial competence: Evidence from micro restaurants in Calabar metropolis, Cross River State, Nigeria. In International Conference on Agricultural Economists, Milan, Italy.

Vanharanta, H., Kantola, J., \& Seikola, S. (2015). Customers' conscious experience in a coffee shop. Procedia Manufacturing, 3, 618-625. doi:https://doi.org/10.1016/j.promfg.2015.07.283

Villarreiz, D. (2012). Your guide to davao city Philippines. Retrieved from https://goo.gl/rhWUDL

Wichailert, K., \& Yousapornpaiboon, K. (2017). Brand equity affects brand loyalty of the bottled mineral drinking water in Thailand. Journal of Administrative and Business Studies, 3(4), 180-191. doi:https://doi.org/10.20474/jabs-3.4.3

Worley, C. G., Williams, T. D., Williams, T., \& Lawler, E. E. (2014). The agility factor: Building adaptable organizations for superior performance. New York, NY: John Wiley \& Sons. 
Wu, M.-Y., \& Tseng, L.-H. (2014). Customer satisfaction and loyalty in an online shop: An experiential marketing perspective. International Journal of Business and Management, 10(1), 104-120. doi:https://doi.org/10.5539/ijbm.v10n1p104

Wuensch, K. (2016). An introduction to path analysis. Retrieved from https://goo.gl/EFvGMV (accessed on 13 June, 2017)

Yasanallah, P., \& Bidram, V. (2012). Studying the status of marketing mix (7Ps) in consumer cooperatives at ilam province from members' perspectives. American Journal of Industrial and Business Management, 2(4), 194-199. doi:https:// doi.org/10.4236/ajibm.2012.24025

Yulisetiarini, D., \& Si, D. M. (2016). The relationship between service quality, customer satisfaction and loyalty in restaurant business in East Java. International Journal of Business and Management Invention, 3(5), 01-10.

Zhang, Y., \& Chung, H. (2016). Strategizing the customer relationship in the independent bookstore network: A case of small small bookshop in Taiwan. International Journal of Business and Administrative Studies, 2(5), 143-150. doi:https:// doi.org/10.20469/ijbas.2.10004-5

Zikmund, W. G., Babin, B. J., Carr, J. C., \& Griffin, M. (2010). Business research methods. Retrieved from https://goo.gl/ $1 \mathrm{CC} 64 \mathrm{G}$ 